\title{
Knowledge, Attitude, and Satisfaction of University Students Regarding Premarital Screening Programs in Kuwait
}

\author{
Khaled Al-Enezi ${ }^{1}$, Amal K. Mitra ${ }^{2 *}$ \\ ${ }^{1}$ Department of Community Medicine and Behavioural Sciences, Faculty of Medicine, Kuwait University, KUWAIT \\ ${ }^{2}$ Department of Epidemiology and Biostatistics, School of Public Health, Jackson State University, Jackson, MS, USA
}

*Corresponding Author: amal.k.mitra@jsums.edu

Citation: Al-Enezi, K. and Mitra, A.K. (2017). Knowledge, Attitude, and Satisfaction of University Students Regarding Premarital Screening Programs in Kuwait. European Journal of Environment and Public Health, 1(2), 07. https:// doi.org/10.20897/ejeph/78075

Published: December 28, 2017

\begin{abstract}
The prevalence of genetic blood disorders is high, ranging from 10-25\%, in Kuwait. This high prevalence is mainly due to a preventable cause, namely, consanguineous marriages. One of the most successful programs in Kuwait implemented to reduce such high prevalence is premarital screening program. The aim of the study was to determine the level of knowledge, attitude and satisfaction among university students regarding premarital screening program, and to find out the factors influencing knowledge, attitude, and satisfaction of the people toward premarital screening program. A cross-sectional study was conducted among 809 students of Kuwait University during July-October 2016. A self-administered questionnaire including 51 questions was handed out to the participants after taking informed consent. The main outcome variables of this study were: knowledge of hereditary diseases, premarital screening, attitude, and satisfaction toward premarital screening program. The mean \pm SD of knowledge score about hereditary diseases was $5.80 \pm 2.9$ out of a total of 14 , and the knowledge score for premarital screening was $3.99 \pm 1.2$ out of 6 . In univariate analysis, knowledge scores about hereditary diseases were significantly associated with marital status $(\mathrm{P}=$ 0.043), education in medical faculties $(\mathrm{P}<0.001)$, higher education of father $(\mathrm{P}=0.027)$, higher education of mother $(\mathrm{P}=0.001)$, and presence of hereditary disease in the family $(\mathrm{P}=0.003)$. The level of attitude toward premarital screening program was significantly associated with female gender $(\mathrm{P}<0.001)$, marital status $(\mathrm{P}=0.023)$, higher years of study $(\mathrm{P}=0.002)$, higher family income $(\mathrm{P}=0.019)$. In multivariate analysis, education in medical faculties and presence of hereditary disease in the family were significant predictors of knowledge about hereditary disease. This study identified some demographic factors which determined the outcome of knowledge about premarital screening and hereditary disease. Also, the study demonstrated that more than $90 \%$ of the people were not satisfied about the premarital screening program, and more than $70 \%$ had to wait for a long time before receiving the test results. These areas of dissatisfaction should be improved for a successful program.
\end{abstract}

Keywords: knowledge, attitudes, university students, premarital screening, hereditary diseases

\section{INTRODUCTION}

Genetic blood disorders are chronic in nature, thus creating a major public health problem that burdens the health care systems and significantly affect the quality of life of the involved patients and their families. Transmission of hereditary diseases occurs through specific patterns: it is either X-linked, autosomal dominant or autosomal recessive. The autosomal recessive transmission happens only if both parents carry the same defective 
gene. Globally, many surveys have concluded that at least 2 in every 1,000 neonates have autosomal recessive disorders (Abdel-Meguid et al., 2000).

Sickle cell anemia and thalassemia major are the most common inherited hemoglobinopathies and are a major public health problem worldwide (Old, 2009). The prevalence of genetic diseases in the member countries of Gulf Cooperation Council (GCC) is high in comparison with rates in Europe and North America. Hemoglobinopathies, G6PD deficiency, inborn errors of metabolism, congenital hypothyroidism, deafness, and Down's syndrome represent the most prevalent genetic diseases in the GCC countries (Al-Jasir et al., 2009).

Sickle cell gene, thalassemia and red cell enzymopathies are the major contributors to genetic diseases in Saudi Arabia (Al-Arrayed et al., 1997). In Kuwait, the prevalence of genetic blood disorders is high, and according to preliminary epidemiological studies the carrier rate for sickle cell anemia is around $10 \%$ to $25 \%$ (Al-Arrayed et al., 2003). It is estimated that $70 \%$ of patients presented with birth defects in Kuwait had inherited genetic defects. Of these, $45 \%$ were autosomal recessive disorders or unknown disorders with a family pattern suggestive of autosomal recessive inheritance (Teebi, 1994). A higher frequency of genetic diseases was found in the first- $(6.97 \%$; $<<$ $0.001)$, second- $(6.78 \% ; \mathrm{p}<0.001)$, and third-cousin $(6.46 \% ; \mathrm{p}=0.022)$ couples' offspring compared with those of non-consanguineous couples (Al-Kandari and Crews, 2011).

Consanguinity is an important issue in the Arab region where, in comparison to other populations, there is a strong preference for consanguineous unions, most frequently contracted between the first cousins (Bittles, 2001). The prevalence of such marriages differs across the Arab region. For example, in the south of Egypt it constitutes $70 \%$ of the marriages while it represents $34 \%$ in the urban areas. A total of 5,007 Kuwaitis were ascertained to study the incidence of consanguineous marriages during 1983. The rate of consanguineous mating was found to be 54.3\% with estimated population incidence rates varying from 52.9 to 55.7\% (Al-Awadi et al., 1985). In Qatar, the rate of overall consanguinity was $51-54 \%$ and that of first-cousin marriage was 33.5\%. In Saudi Arabia, the rate of overall consanguinity was $57.7 \%$ and the first-cousin consanguinity was 31\% (Al-Jasir et al., 2009). In Bahrain, there has been a significant reduction in the rate of consanguineous marriage from $39 \%$ to $20 \%$ over 18 years after the introduction of the genetic preventive campaign program implemented in 1980s. This reduction in consanguinity was accompanied by corresponding decrease in the prevalence of genetic diseases in the country (Al-Arayyed et al., 2007).

Mandatory premarital screening program have been implemented into high-risk populations worldwide since the 1970's (McGeorge and Carlson, 2006; Wang et al., 2013) with a remarkable success. The success of thalassemia control program of Cyprus is a promising example of how measures such as health education, carrier screening, premarital counseling and prenatal diagnosis can reduce the incidence of B-thalassemia major (Saxena and Phadke, 2002). Similarly, in Turkey, the four years result of the premarital screening program was reported to be a very useful and effective way of controlling thalassemia major (Keskin et al., 2000). In Saudi Arabia, complete blood count, sickle cell test, and hemoglobin-electrophoresis were used in the premarital screening, resulting into more than $70 \%$ reduction of the prevalence of B-thalassemia during the period of $2004-2009$ (Memish and Saeedi, 2011).

In order to avoid the financial, psychological and social burdens that are usually present among families with children affected by genetic and chronic infectious diseases, the State of Kuwait passed the Premarital Law No. $31 / 2008$ which mandates the premarital screening to maintain protection against diseases that can be transmitted by marriage (Ministry of Health, Kuwait, 2008).

The aims of the study were twofold: 1) to assess the knowledge, attitude, and satisfaction of university students regarding the premarital screening program in Kuwait; and 2) to determine the socio-demographic factors modifying the knowledge about hereditary diseases and premarital screening programs.

\section{METHOD}

\section{Study Design and Population}

This was a cross-sectional study that was conducted among students of Kuwait University. The faculties in Kuwait University included in the study were: Medicine, Dentistry, Nursing and Allied Health as medical-based colleges; and Faculty of Education, Social Educations, Law, Engineering and Shari'a as non-medical-based colleges. This study included both Kuwaitis and non-Kuwaitis of either gender, irrespective of their marital status. The study targeted university students because the mean age at marriage for Kuwaiti males and females was about 26 and 24 years, respectively (Shah, 2010).

The research proposal was approved by the Ethics Committee of Health Science Center, Kuwait University, and the Ministry of Health. An informed consent was obtained from all the participants before enrollment. 


\section{Questionnaire and Data Collection Procedure}

Data was collected using a pre-tested closed-ended structured questionnaire comprising of 51 questions. Participants were asked to complete a self-addressed questionnaire which took about 10 minutes to fill out. The student researcher was available to answer any questions while completing the questionnaire. The questionnaire was initially formulated in English then translated into Arabic which is the spoken language of the target population. The questionnaire included the following components: Part A: Questions related to sociodemographic characteristics of the participants (14 questions); Part B: Questions to assess knowledge of hereditary diseases, premarital screening and genetic counseling programs (25 questions; yes/no/don't know format); Part C: Questions to assess attitude toward premarital screening program (6 questions in a 5-point Likert Scale); and Part D: Questions to assess satisfaction about premarital screening program for married only (6 questions in a 5-point Likert Scale).

Questions related to knowledge and attitude were asked to both married and unmarried people; however, the satisfaction questions were only for those who were married. Pilot testing of the questionnaire was done among 20 participants at the Faculty of Engineering to verify the acceptance and to ensure coherence of the questionnaire.

\section{Statistical Methods}

Data was entered and analyzed using IBM SPSS Statistics for Windows, Version 23.0 (Armonk, NY: IBM Corp). Descriptive analysis was performed for socio-demographic variables and for variables related to knowledge about hereditary diseases. Chi-square test was used to test the significance between different categorical variables. For each correct answer of the knowledge questions, participants were given 1 point and for each incorrect or "don't know" answers he/she received " 0 " point. A composite score of knowledge was calculated for the total knowledge scores. To distinguish participants with different levels of knowledge (poor or satisfactory), the score was recorded into categories according to a prior cutoff point based on quartiles in which the first quartile represented the poor and the remaining represented the satisfactory score.

The participants' knowledge about hereditary diseases was assessed through a score based on the responses to 14 questions. A score from 0 to 4 reflected poor knowledge, whereas a score from 5 to 14 reflected satisfactory knowledge. The knowledge of premarital screening (PMS) program was assessed through a score based on the responses to 6 questions. A score from 0 to 3 reflected poor knowledge, whereas a score from 4 to 6 reflected satisfactory knowledge of PMS.

The participants' attitude toward premarital screening was assessed through a score based on the responses to 6 attitudinal statements on the form of five to one points Likert scale. A prior cutoff point was selected at the first quartile value which was 20 . A score from 6 to 20 reflected unfavorable attitudes whereas a score of 21 to 30 reflected favorable attitude.

The participant's satisfaction toward premarital screening was assessed through a score based on the responses to 6 satisfaction statements on a five-point Likert scale. A prior cutoff point was selected at the first quartile value which was 20. A score from 6 to 20 reflected poor response whereas a score of 21 to 30 reflected satisfactory response.

The main outcome variables in this study were the knowledge of both hereditary diseases and premarital screening program and attitude toward premarital screening program. The determinants of knowledge score and attitude were assessed using univariate analysis and then multivariate model to control for confounders. A p-value of 0.05 or less and $95 \%$ confidence internals were used for statistical significance.

\section{Estimation of Sample Size}

The sample size was estimated using a software called GPower, version 3.0.10. Since there was no published data about the prevalence of knowledge regarding premarital screening and genetic counseling programs in Kuwait, the prevalence of such information was obtained from Saudi Arabia which represented a similar society. The proportion of people having knowledge about premarital screening was $21.9 \%$ and $35 \%$ among males and females, respectively (Al-Aama et al., 2008). With a $95 \%$ confidence interval, a precision of $5 \%$, and $80 \%$ power, the estimated sample size was 737 . With a $10 \%$ dropout sample size was 810 .

\section{RESULTS}

A total of 850 students who fulfilled the eligibility criteria were approached; of them 810 participated in the study, yielding a response rate of $95 \%$. One of them was dropped from the analysis because of having incomplete information. 
Table 1. Socio-demographic characteristics of Kuwait university students $(n=809)$

\begin{tabular}{|c|c|c|c|}
\hline \multirow{2}{*}{\multicolumn{2}{|c|}{ Socio-demographic characteristics }} & \multicolumn{2}{|c|}{ Frequency } \\
\hline & & $\mathbf{N}$ & $\%$ \\
\hline \multirow{4}{*}{ Age } & mean age $( \pm \mathrm{SD})$ & $21.27(3.7$ & \\
\hline & $<20$ & 234 & 28.9 \\
\hline & $20-24$ & 498 & 61.6 \\
\hline & $\geq 25$ & 77 & 9.5 \\
\hline \multirow{2}{*}{ Gender } & Male & 292 & 36.1 \\
\hline & Female & 517 & 63.9 \\
\hline \multirow{2}{*}{ Nationality } & Kuwaiti & 723 & 89.4 \\
\hline & Non-Kuwaiti & 86 & 10.6 \\
\hline \multirow{2}{*}{ Marital status } & Married /Divorced/Widowed & 161 & 19.9 \\
\hline & Not married & 648 & 80.0 \\
\hline \multirow{2}{*}{ Faculty of Education } & Medical & 92 & 11.4 \\
\hline & Non-medical & 717 & 88.6 \\
\hline \multirow{2}{*}{ Year of study } & $1-2$ & 301 & 37.2 \\
\hline & $\geq 3$ & 508 & 62.8 \\
\hline \multirow{3}{*}{ No. of siblings including participant } & $\leq 3$ & 96 & 12.2 \\
\hline & $4-7$ & 504 & 63.8 \\
\hline & $\geq 8$ & 190 & 24.0 \\
\hline \multirow{2}{*}{ Father's education Level } & High School and Less & 354 & 44.1 \\
\hline & Diploma and More & 448 & 55.9 \\
\hline \multirow{2}{*}{ Mother's education Level } & High School and Less & 340 & 42.4 \\
\hline & Diploma and More & 462 & 57.6 \\
\hline \multirow{4}{*}{ Family monthly Income (KD) } & Less than 1000 & 57 & 7.3 \\
\hline & 1000 to $<1500$ & 239 & 30.5 \\
\hline & 1500 to $<2000$ & 214 & 27.3 \\
\hline & 2000 or more & 273 & 34.9 \\
\hline \multirow{3}{*}{$\begin{array}{r}\text { Is your spouse related to you (cousin or } \\
\text { other)? }\end{array}$} & Yes, cousin & 51 & 33.1 \\
\hline & Yes, other & 37 & 24.0 \\
\hline & No & 66 & 42.9 \\
\hline \multirow{2}{*}{ Are your parents related (cousin or other)? } & Yes & 369 & 45.9 \\
\hline & No & 435 & 54.1 \\
\hline \multirow{2}{*}{ Family origin } & Badoo & 440 & 59.9 \\
\hline & Hather & 295 & 40.1 \\
\hline \multirow{2}{*}{$\begin{array}{r}\text { Does anyone in your family have inherited } \\
\text { disease? }\end{array}$} & Yes & 326 & 41.4 \\
\hline & No & 461 & 58.6 \\
\hline
\end{tabular}

\section{Socio-demographic Data}

Table 1 shows that the participants were young adults with a mean \pm SD age of $21.27 \pm 3.7$ years; the majority (64\%) were females, and $89 \%$ were Kuwaitis. The predominant number of participants $(88.6 \%)$ were from nonmedical faculties, and $11 \%$ represented medical faculties. About $63 \%$ had their college education of 3 years or more. More than $50 \%$ of the parents had diploma or more education. More than $62 \%$ had a monthly income of KD 1,500 or more (US $\$ 4,950$ or more). Of the family origin, about $60 \%$ were Badoos.

Interestingly, $57 \%$ of the participants mentioned that their spouses were their first cousins or otherwise related, and $46 \%$ of their parents were also related (cousin or other). Approximately, $41 \%$ of the participants also mentioned that they had someone in their family suffering from an inherited disease.

\section{Knowledge about Hereditary Disease}

The mean \pm SD of knowledge score about hereditary diseases was $5.80 \pm 2.9$ out of a total of 14 . About $89 \%$ mentioned correctly that consanguinity marriage leads to hereditary diseases; $59 \%$ mentioned that sickle cell disease is hereditary; and 31\% identified thalassemia as a hereditary disease (Figure 1). However, about one-third of the people were incorrect in their statement that gastritis, and gonorrhea are hereditary diseases, and that pregnancy complications, X-ray during pregnancy, and hypertension lead to hereditary diseases. Although a majority (65\%) believed that hereditary diseases are preventable, only $13 \%$ mentioned that they are curable. The knowledge scores were significantly higher among the students of medical faculties compared to those of non-medical faculties $(\mathrm{P}<$ 0.001) (Figure 2). 


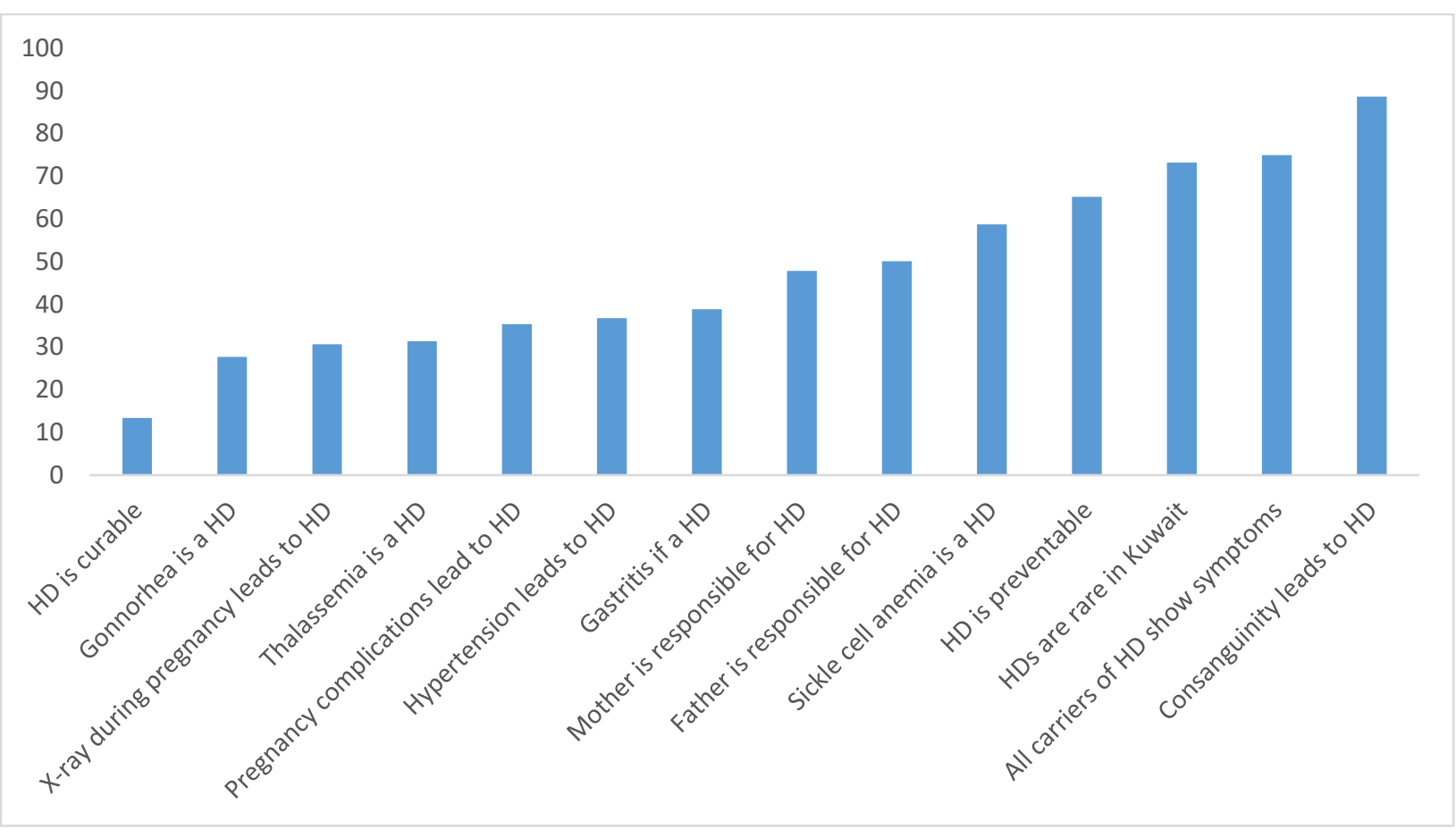

Figure 1. Knowledge about hereditary disease (HD). Numbers are in percentage.

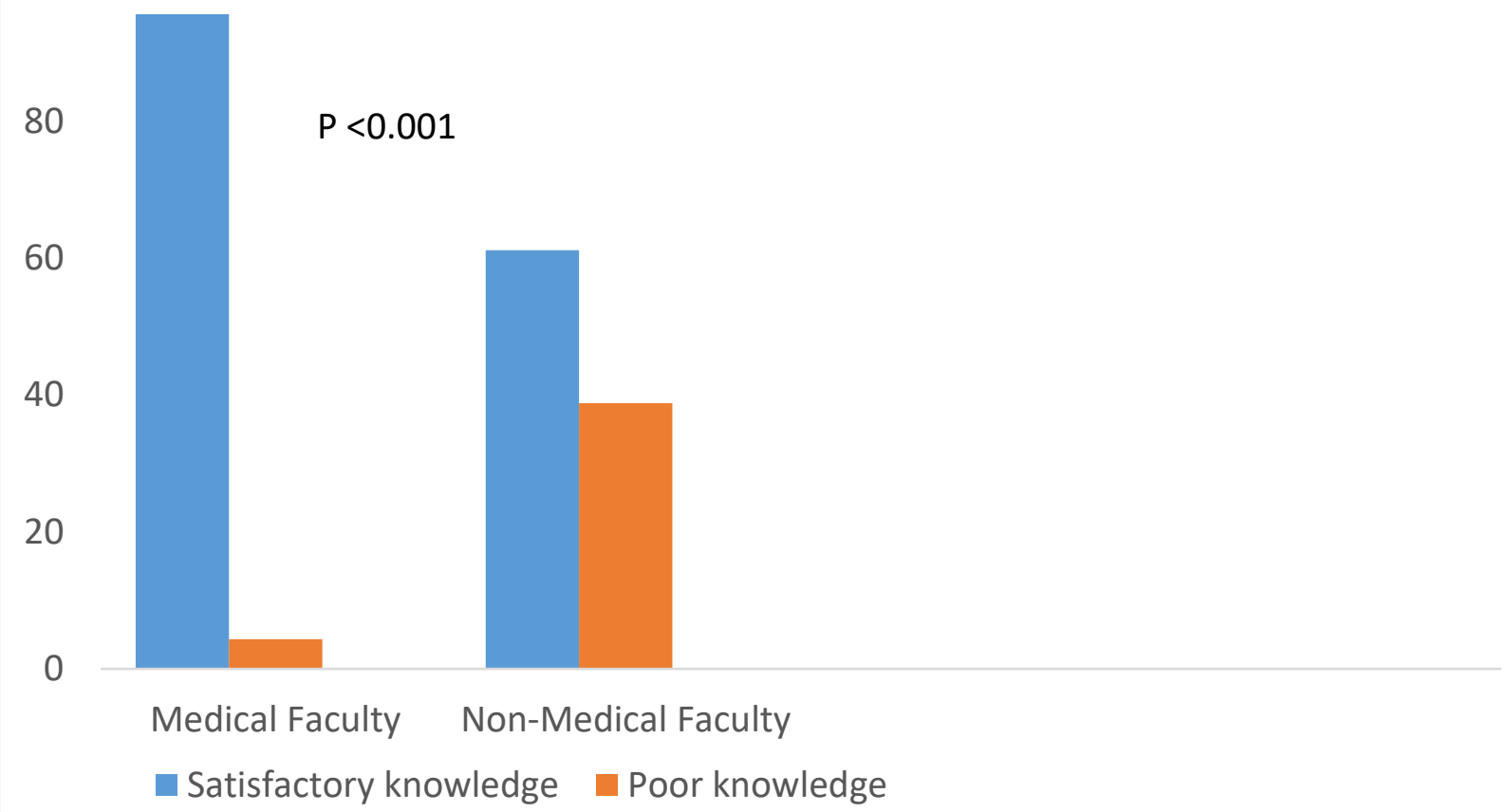

Figure 2. Knowledge about hereditary diseases among medical and non-medical faculty students. Numbers are in percentage.

Table 2 shows that several sociodemographic variables were significantly associated with a higher knowledge score about hereditary diseases: unmarried vs. married people ( $66.9 \%$ vs. $58.4 \%, \mathrm{P}=0.04)$; medical faculty vs. nonmedical faculty $(95.7 \%$ vs. $61.2 \%, \mathrm{P}<0.001)$; father's education of diploma and more vs. high school or less education (68.4 vs. $60.9 \%, \mathrm{P}=0.0277)$; mother's education diploma or more vs. high school or less education ( $70.3 \%$ vs. $58.7 \%, \mathrm{P}=0.001)$; and presence of a hereditary disease in the family vs. no such diseases $(72 \%$ vs. $62 \%$, $\mathrm{P}=0.003)$. 
Table 2. Relationship between knowledge about hereditary diseases and socio-demographic factors among Kuwait university students

\begin{tabular}{|c|c|c|c|c|c|c|}
\hline \multirow{2}{*}{\multicolumn{2}{|c|}{ Socio-demographic factors }} & \multicolumn{2}{|c|}{ Poor } & \multicolumn{2}{|c|}{ Satisfactory } & \multirow{2}{*}{ P-value } \\
\hline & & $\mathbf{N}$ & $\%$ & $\mathbf{N}$ & $\%$ & \\
\hline \multirow{3}{*}{ Age } & $<20$ & 85 & 37.9 & 139 & 62.1 & \multirow{3}{*}{0.097} \\
\hline & $20-24$ & 160 & 32.2 & 337 & 67.8 & \\
\hline & $\geq 25$ & 33 & 42.9 & 44 & 57.1 & \\
\hline \multirow{2}{*}{ Gender } & Male & 105 & 36.5 & 183 & 63.5 & \multirow{2}{*}{0.470} \\
\hline & Female & 173 & 33.9 & 337 & 66.1 & \\
\hline \multirow{2}{*}{ Nationality } & Kuwaiti & 249 & 35.0 & 463 & 65.0 & \multirow{2}{*}{0.818} \\
\hline & Non-Kuwaiti & 29 & 33.7 & 57 & 66.3 & \\
\hline \multirow{2}{*}{ Marital status } & Married/Divorced/widowed & 67 & 41.6 & 94 & 58.4 & \multirow{2}{*}{0.043} \\
\hline & Not married & 211 & 33.1 & 426 & 66.9 & \\
\hline \multirow{2}{*}{ Faculty of education } & Medical & 4 & 4.3 & 88 & 95.7 & \multirow{2}{*}{$0>.001$} \\
\hline & Non-medical & 274 & 38.8 & 432 & 61.2 & \\
\hline \multirow{2}{*}{ Year of study } & $1-2$ & 111 & 38.1 & 180 & 61.9 & \multirow{2}{*}{0.137} \\
\hline & $\geq 3$ & 167 & 32.9 & 340 & 67.1 & \\
\hline \multirow{2}{*}{ Father's education level } & High School and Less & 137 & 39.1 & 213 & 60.9 & \multirow{2}{*}{0.027} \\
\hline & Diploma and More & 140 & 31.6 & 303 & 68.4 & \\
\hline \multirow{2}{*}{ Mother's education level } & High School and Less & 138 & 41.3 & 196 & 58.7 & \multirow{2}{*}{0.001} \\
\hline & Diploma and More & 136 & 29.7 & 322 & 70.3 & \\
\hline \multirow{4}{*}{ Family monthly income (KD) } & Less than 1000 & 18 & 32.7 & 37 & 67.3 & \multirow{4}{*}{0.088} \\
\hline & 1000 to $<1500$ & 98 & 41.4 & 139 & 58.6 & \\
\hline & 1500 to $<2000$ & 72 & 34.1 & 139 & 65.9 & \\
\hline & 2000 or more & 84 & 30.8 & 189 & 69.2 & \\
\hline \multirow{2}{*}{$\begin{array}{r}\text { Does anyone in your family suffer } \\
\text { from any inherited diseases? }\end{array}$} & Yes & 91 & 27.9 & 235 & 72.1 & \multirow{2}{*}{0.003} \\
\hline & No & 176 & 38.2 & 285 & 61.8 & \\
\hline
\end{tabular}

Table 3. Relationship between level of knowledge about premarital screening program and socio-demographic factors among Kuwait university students

\begin{tabular}{|c|c|c|c|c|c|c|}
\hline \multirow{2}{*}{\multicolumn{2}{|c|}{ Socio-demographic factors }} & \multicolumn{2}{|c|}{ Poor } & \multicolumn{2}{|c|}{ Satisfactory } & \multirow{2}{*}{ P-value } \\
\hline & & $\mathbf{N}$ & $\%$ & $\mathbf{N}$ & $\%$ & \\
\hline \multirow{3}{*}{ Age } & $<20$ & 69 & 35.9 & 123 & 64.1 & \multirow{3}{*}{$0>.001$} \\
\hline & $20-24$ & 137 & 29.7 & 324 & 70.3 & \\
\hline & $\geq 25$ & 6 & 8.2 & 67 & 91.8 & \\
\hline \multirow{2}{*}{ Gender } & Male & 98 & 38.0 & 160 & 62.0 & \multirow{2}{*}{$>0.001$} \\
\hline & Female & 114 & 24.4 & 354 & 75.6 & \\
\hline \multirow{2}{*}{ Nationality } & Kuwaiti & 183 & 28.1 & 469 & 71.9 & \multirow{2}{*}{0.046} \\
\hline & Non-Kuwaiti & 29 & 39.2 & 45 & 60.8 & \\
\hline \multirow{2}{*}{ Marital status } & Married/Divorced/widowed & 19 & 12.5 & 133 & 87.5 & \multirow{2}{*}{$>0.001$} \\
\hline & Not married & 193 & 33.6 & 381 & 66.4 & \\
\hline \multirow{2}{*}{ Faculty of education } & Medical & 28 & 32.2 & 59 & 67.8 & \multirow{2}{*}{0.514} \\
\hline & Non-medical & 184 & 28.8 & 455 & 71.2 & \\
\hline \multirow{2}{*}{ Year of study } & $1-2$ & 91 & 35.3 & 167 & 64.7 & \multirow{2}{*}{0.008} \\
\hline & $\geq 3$ & 121 & 25.9 & 347 & 74.1 & \\
\hline \multirow{3}{*}{$\begin{array}{r}\text { No. of siblings including } \\
\text { participant }\end{array}$} & $\geq 3$ & 31 & 37.8 & 51 & 62.2 & \multirow{3}{*}{0.003} \\
\hline & $4-7$ & 143 & 31.1 & 317 & 68.9 & \\
\hline & $\geq 8$ & 33 & 19.3 & 138 & 80.7 & \\
\hline \multirow{2}{*}{ Father's education level } & High School and Less & 86 & 27.2 & 230 & 72.8 & \multirow{2}{*}{0.295} \\
\hline & Diploma and More & 125 & 30.8 & 281 & 69.2 & \\
\hline \multirow{2}{*}{ Mother's education level } & High School and Less & 69 & 22.6 & 236 & 77.4 & \multirow{2}{*}{0.001} \\
\hline & Diploma and More & 142 & 34.1 & 274 & 65.9 & \\
\hline \multirow{4}{*}{ Family monthly income (KD) } & Less than 1000 & 13 & 28.3 & 33 & 71.7 & \multirow{4}{*}{0.789} \\
\hline & 1000 to $<1500$ & 58 & 27.5 & 153 & 72.5 & \\
\hline & 1500 to $<2000$ & 61 & 31.6 & 132 & 68.4 & \\
\hline & 2000 or more & 72 & 27.8 & 187 & 72.2 & \\
\hline \multirow{2}{*}{$\begin{array}{l}\text { Does anyone in your family suffer } \\
\text { from any inherited diseases? }\end{array}$} & Yes & 76 & 25.0 & 228 & 75.0 & \multirow{2}{*}{0.033} \\
\hline & No & 135 & 32.3 & 283 & 67.7 & \\
\hline
\end{tabular}

\section{Knowledge about Premarital Screening Program}

Ninety two percent $(727 / 789)$ had heard about premarital screening. When asked about the sources of the information, many had multiple answers: friends or relatives (91\%), media $(70 \%)$, health workers $(33 \%)$, and school $(55 \%)$. The knowledge score for premarital screening was $3.99 \pm 1.2$ out of 6 . According to Table 3, factors that were significantly associated with a better knowledge score about premarital screening program were: older age ( $\mathrm{P}$ $<0.001)$, female gender $(\mathrm{P}<0.001)$, Kuwaiti nationality $(\mathrm{P}=0.046)$, marital status $(\mathrm{P}<0.001)$, higher years of 
Table 4. Relationship between level of attitude toward premarital screening program and socio-demographic factors among Kuwait university students

\begin{tabular}{|c|c|c|c|c|c|c|}
\hline \multirow{2}{*}{\multicolumn{2}{|c|}{ Socio-demographic factors }} & \multicolumn{2}{|c|}{ Poor } & \multicolumn{2}{|c|}{ Satisfactory } & \multirow{2}{*}{ P-value } \\
\hline & & $\mathbf{N}$ & $\%$ & $\mathbf{N}$ & $\%$ & \\
\hline \multirow{3}{*}{ Age } & $<20$ & 36 & 17.9 & 165 & 82.1 & \multirow{3}{*}{0.239} \\
\hline & $20-24$ & 62 & 13.1 & 412 & 86.9 & \\
\hline & $\geq 25$ & 12 & 16.7 & 60 & 83.3 & \\
\hline \multirow{2}{*}{ Gender } & Male & 58 & 21.5 & 212 & 78.5 & \multirow{2}{*}{$<0.001$} \\
\hline & Female & 52 & 10.9 & 425 & 89.1 & \\
\hline \multirow{2}{*}{ Nationality } & Kuwaiti & 93 & 13.9 & 574 & 86.1 & \multirow{2}{*}{0.081} \\
\hline & Non-Kuwaiti & 17 & 21.2 & 63 & 78.8 & \\
\hline \multirow{2}{*}{ Marital status } & Married/Divorced/widowed & 13 & 8.8 & 135 & 91.2 & \multirow{2}{*}{0.023} \\
\hline & Not married & 97 & 16.2 & 502 & 83.8 & \\
\hline \multirow{2}{*}{ Faculty of education } & Medical & 10 & 11.1 & 80 & 88.9 & \multirow{2}{*}{0.302} \\
\hline & Non-medical & 100 & 15.2 & 557 & 84.8 & \\
\hline \multirow{2}{*}{ Year of study } & $1-2$ & 53 & 20.1 & 211 & 79.9 & \multirow{2}{*}{0.002} \\
\hline & $\geq 3$ & 57 & 11.8 & 246 & 88.2 & \\
\hline \multirow{2}{*}{ Father's education level } & High School and Less & 48 & 15.3 & 266 & 84.7 & \multirow{2}{*}{0.694} \\
\hline & Diploma and More & 61 & 14.3 & 367 & 85.7 & \\
\hline \multirow{2}{*}{ Mother's education level } & High School and Less & 48 & 15.6 & 259 & 84.4 & \multirow{2}{*}{0.541} \\
\hline & Diploma and More & 61 & 14.0 & 374 & 86.0 & \\
\hline \multirow{4}{*}{ Family monthly income (KD) } & Less than 1000 & 12 & 25.0 & 36 & 75.0 & \multirow{4}{*}{0.019} \\
\hline & 1000 to $<1500$ & 36 & 16.5 & 182 & 83.5 & \\
\hline & 1500 to $<2000$ & 31 & 15.9 & 164 & 84.1 & \\
\hline & 2000 or more & 26 & 9.8 & 238 & 90.2 & \\
\hline \multirow{2}{*}{$\begin{array}{l}\text { Does anyone in your family suffer } \\
\text { from any inherited diseases? }\end{array}$} & Yes & 42 & 13.6 & 267 & 86.4 & \multirow{2}{*}{0.547} \\
\hline & $\mathrm{No}$ & 66 & 15.2 & 369 & 84.8 & \\
\hline
\end{tabular}

study (3 years or more) $(\mathrm{P}=0.008)$; more number of siblings $(\mathrm{P}=0.003)$, mother's education of diploma and higher $(\mathrm{P}=0.001)$, and presence of hereditary disease in the family $(\mathrm{P}=0.033)$.

\section{Attitude towards Premarital Screening Program}

The majority opined that 1 ) they should not be comfortable before doing premarital screening test (92\%); 2$)$ premarital screening does not conflict with customs and tradition $(83 \%) ; 3)$ premarital screening does not conflict with the religion (83\%); and 4) premarital screening is not against the principle of confidentiality (88\%). Twenty eight percent (196/709) mentioned that premarital screening tests can decrease the burden of disease in the society. Only $14 \%$ opined against premarital screening. It is also important to mention that $40 \%$ were in agreement that "the results of premarital screening should not influence my marriage decision".

In univariate analysis (Table 4), female gender $(\mathrm{P}=<0.001)$, marital status $(\mathrm{P}=0.023)$, higher years of study $(\mathrm{P}=0.002)$, and higher income $(\mathrm{P}=0.019)$ were significantly associated with better attitude score toward premarital screening program.

\section{Satisfaction Regarding Premarital Screening Program}

In general, the people were not satisfied regarding premarital screening program. The major areas of dissatisfaction included: 1 ) the health workers did not explain the procedure of the premarital screening program $(56 \%) ; 2)$ the procedure was not smooth and free of complications $(85 \%) ; 3)$ had to wait for a long time before receiving the test results (71\%); and 4) not satisfied in general about the program (93\%).

\section{Multivariate Analysis}

In multiple logistic regression analysis, a better knowledge about hereditary diseases was significantly predicted by education in medical faculties (adjusted $\mathrm{OR}=12.74,95 \% \mathrm{CI}=4.39,36.94$ ), if parents were not related (cousin or other) (adjusted OR $=1.41,95 \% \mathrm{CI}=1.01,1.98$ ), and presence of any hereditary disease in the family (adjusted $\mathrm{OR}=1.42,95 \% \mathrm{CI}=1.00,2.02)$, after adjusting for other demographic variables including age, gender, marital status, number of siblings, parents' education, family income, and family origin (Badoo or Hather) (Table 5). Only one variable, spouse being not related (cousin or other) was significantly associated with knowledge about premarital screening program (adjusted $\mathrm{OR}=5.29,95 \% \mathrm{CI}=1.09,25.75$ ), after adjusting for other demographic variables (Table 6). 
Table 5. Relationship between knowledge about hereditary diseases and socio-demographic factors among Kuwait university students using multivariable logistic regression

\begin{tabular}{|c|c|c|c|c|c|c|}
\hline \multicolumn{3}{|c|}{ Socio-demographic factors } & \multirow{2}{*}{$\begin{array}{l}\mathbf{N} \\
92\end{array}$} & \multirow{2}{*}{\begin{tabular}{|c|}
$\begin{array}{c}\text { Adjusted } \\
\text { odds ratio }\end{array}$ \\
12.74
\end{tabular}} & \multirow{2}{*}{$\frac{(\mathbf{9 5} \% \mathbf{C I})}{(4.39,36.94)}$} & \multirow{2}{*}{$\begin{array}{r}\text { P-value } \\
0>.001\end{array}$} \\
\hline Faculty of education & Medical & & & & & \\
\hline Faculty of education & Non-medical & Reference & 717 & 1.0 & & \\
\hline \multirow{2}{*}{ Year of study } & $1-2$ & Reference & & 1.0 & & \\
\hline & $\geq 3$ & & & 1.42 & $(0.86,2.36)$ & 0.175 \\
\hline \multirow{2}{*}{$\begin{array}{r}\text { Are your parents related (cousin or } \\
\text { other)? }\end{array}$} & Yes & Reference & 369 & 1.0 & & \\
\hline & No & & 435 & 1.41 & $(1.01,1.98)$ & 0.046 \\
\hline \multirow{2}{*}{$\begin{array}{r}\text { Does anyone in your family suffer } \\
\text { from any inherited diseases? }\end{array}$} & Yes & & 326 & 1.42 & $(1.00,2.02)$ & 0.05 \\
\hline & No & Reference & 461 & 1.0 & & \\
\hline
\end{tabular}

adjusted for age, gender, nationality, marital status, number of siblings, parents' education, family income, and family origin (Badoo or

Hather). $\mathrm{CI}=$ confidence intervals.

Table 6. Relationship between knowledge about premarital screening program and socio-demographic variables among Kuwait university students using multivariable logistic regression

\begin{tabular}{|c|c|c|c|c|c|c|}
\hline \multicolumn{3}{|c|}{ Socio-demographic factors } & \multirow{2}{*}{$\frac{\mathbf{N}}{326}$} & \multirow{2}{*}{$\begin{array}{c}\begin{array}{c}\text { Adjusted } \\
\text { odds ratio }^{\text {a }}\end{array} \\
1.99\end{array}$} & \multirow{2}{*}{$\frac{(\mathbf{9 5 \%} \mathbf{C I})}{(0.57,6.97)}$} & \multirow{2}{*}{$\begin{array}{c}\text { P-value } \\
0.282\end{array}$} \\
\hline Does anyone in your family suffer & Yes & & & & & \\
\hline from any inherited disease? & No & Reference & 461 & 1.0 & & \\
\hline \multirow{2}{*}{$\begin{array}{r}\text { Is your spouse related to you } \\
\text { (cousin or other)? }\end{array}$} & Yes & Reference & 88 & 1.0 & & \\
\hline & No & & 66 & 5.29 & $(1.09,25.75)$ & 0.039 \\
\hline \multirow{2}{*}{$\begin{array}{r}\text { Are your parents related (cousin or } \\
\text { other)? }\end{array}$} & Yes & Reference & 369 & 1.0 & & \\
\hline & No & & 435 & 2.16 & $(0.62,7.50)$ & 0.226 \\
\hline \multirow{2}{*}{ Family origin } & Badoo & Reference & 440 & 1.0 & & \\
\hline & Hather & & 295 & 1.45 & $(0.20,10.40)$ & 0.710 \\
\hline
\end{tabular}

aAdjusted for age, gender, nationality, marital status, number of siblings, parents' education, and family income. CI = confidence intervals.

Table 7. Relationship between level of attitude toward premarital screening program and socio-demographic variables among Kuwait university students using multivariable logistic regression

\begin{tabular}{|c|c|c|c|c|c|c|}
\hline Socio-demogr & phic factors & & $\mathbf{N}$ & $\begin{array}{c}\text { Adjusted } \\
\text { odds ratio }^{\mathrm{a}}\end{array}$ & $(95 \% \mathrm{CI})$ & P-value \\
\hline \multirow{2}{*}{ Gender } & Male & Reference & 292 & 1.0 & & \\
\hline & Female & & 517 & 2.23 & $(1.33,3.73)$ & 0.002 \\
\hline \multirow{2}{*}{ Year of study } & $1-2$ & Reference & 301 & 1.0 & & \\
\hline & $\geq 3$ & & 508 & 2.65 & $(1.35,5.21)$ & 0.005 \\
\hline \multirow{4}{*}{ Family monthly Income (KD) } & Less than 1000 & Reference & 57 & 1.0 & & \\
\hline & 1000 to $<1500$ & & 239 & 2.81 & $(1.13,7.03)$ & 0.027 \\
\hline & 1500 to $<2000$ & & 214 & 2.85 & $(1.10,7.38)$ & 0.031 \\
\hline & 2000 or more & & 273 & 3.84 & $(1.45,10.19)$ & 0.007 \\
\hline
\end{tabular}

aAdjusted for age, nationality, marital status, faculty of education, number of siblings, parents' education, presence of any hereditary diseases in the family, and family origin (Badoo or Hather). CI = confidence intervals.

For the level of attitude toward premarital screening program, the significant predictors were: female gender (adjusted $\mathrm{OR}=2.23,95 \% \mathrm{CI}=1.33,3.73$ ), higher years of study (adjusted $\mathrm{OR}=2.65,95 \% \mathrm{CI}=1.35,5.21$ ), and higher income levels of KD $1000-<1500$ (adjusted OR $=2.81,95 \% \mathrm{CI}=1.13,7.03$ ), $\mathrm{KD} 1500-<2000$ (adjusted $\mathrm{OR}=2.85,95 \% \mathrm{CI}=1.10,7.38)$, and $\mathrm{KD} 2000$ and more $($ adjusted $\mathrm{OR}=3.84,95 \% \mathrm{CI}=1.45,10.19)($ Table 7$)$.

\section{DISCUSSION}

This study identified a poor knowledge about hereditary disease and the importance of premarital screening among university students in Kuwait. However, the knowledge score about hereditary diseases was higher among students of medical faculties compared to those of non-medical faculties. Another determinant factor of increased knowledge about hereditary diseases was the presence of any hereditary diseases in the family.

In Saudi Arabia, a recent study among college students showed that students had a good knowledge of genetics, and that the majority had positive attitudes toward genetic testing. The predictors of better knowledge was medical faculty and higher academic year of education (Olwi et al., 2016).

The European Society of Human Genetics recommends several interventions to prevent genetic diseases, including genetic literacy of health-care professionals, and availability of information on genetic testing to the public (van El and Cornel, 2011). The provision of premarital law enacted in 2008 in Kuwait allows mandatory 
premarital screening program for unmarried Kuwaiti nationals. Since the program targets only Kuwaitis, they were found to gain most on the knowledge score for premarital screening program in the country $(\mathrm{P}=0.046)$. However, a general poor knowledge of the college students regarding specific issues, such as the importance of premarital screening and diseases that are considered hereditary indicates the need for more emphasis on genetics in the college curriculum.

Overall, the majority (92\%) of the participants knew about the existence of the PMS program in the country. This finding was similar to a study done in Oman among adults attending primary healthcare centers (Al-Farsi et al., 2014). Most of the participants (89\%) heard about PMS program from health workers, friend/relatives, and media. The main sources of knowledge about premarital screening were from friends (61\%), media (36\%), and medical curriculum (22\%), as reported in another study in Saudi Arabia (Alghamdi et al., 2016). In our study, the predominant source of information were from friends and relatives $(91 \%)$. Interestingly, about one-third of the participants in Oman (Al-Farsi et al., 2014) were not in favor of premarital blood screening test: $36 \%$ of them were due to lack of awareness, $13 \%$ had lack of testing centers, $10 \%$ expressed of no interest, $9 \%$ mentioned they did not have any hereditary disease in the family, and 7\% considered it not important. A similar negative attitude against performing mandatory premarital screening was observed among university students in North Jordan (Alkhaldi et al., 2016), mainly because of the fear that such screening test would affect their future marriage opportunities. On the contrary, $92 \%$ of the people in our study knew about PMS program in Kuwait, and $28 \%$ believed that premarital screening is important in terms of decreasing the burden of disease in the society. This high rate of acceptance of the program in Kuwaitis could be due to the fact that the hereditary disease is quite prevalent in the community, as $41 \%$ of the participants mentioned that someone in the family were suffering from a similar illness, or because the program has been mandatory by law in the country, or both.

In our study, females had significantly higher scores of knowledge about PMS program. It is similar to the results obtained from university students in north Jordan (Alkhaldi et al., 2016) and Syria (Gharaibeh and Mater, 2009). Ganczak (2010) also reported that females in United Arab Emirates expressed a higher importance to premarital testing. It can be explained that women worry more about the existence of life-lasting diseases that burden the quality of life of both mothers and children. When asked about family size, the knowledge score about PMS program was significantly increased with families having more siblings. This may be explained by the fact that families having more members were more likely to go through the mandatory premarital screening program, and that family members passed the information about the program to their younger siblings.

In general, the majority of Kuwait university students (85\%) showed positive attitude towards PMS program. This favorable attitude is similar to a study done among university students in Oman (Al-Kindi et al., 2012). Yet, when the students were asked: "I should be comfortable before doing premarital screening test", more than 90\% expressed a negative attitude. When they were asked: "the result of premarital screening should not influence my marriage decision", about $40 \%$ and $35 \%$ expressed negative and uncertain attitudes, respectively. This demonstrates that although PMS test is mandatory for the formal process of issuing a safe marriage certificate in Kuwait, many couples and their families take it as the last step in the process of the marriage. It is also noteworthy that withdrawing from marriage based on the results of PMS test is difficult in this culture. Hence, there is a need for a well-organized ongoing community campaign about hereditary diseases that can facilitate the PMS program.

One of the potential limitations of this study was that there was no standardized criteria for knowledge and attitude scoring. Based on the distribution of data, we used the first quartile as "poor" and the rest as "satisfactory" groups. Because of the nature of the cross sectional study, we could only show the association but could not establish any causal relationship between the associated factors and the outcome variables.

\section{CONCLUSION}

This study identified an overall poor knowledge on hereditary diseases, especially among students of nonmedical faculties. Because of the observed misconception about hereditary diseases in about one-third of the study population, there is scope to improve the knowledge through organized mass media campaign and by emphasizing on genetics and hereditary diseases in the college curriculum. Genetic educational programs targeting youths should improve their perceived knowledge on consequences of consanguineous marriage.

\section{ACKNOWLEDGEMENT}

The authors are grateful to Ajitha Suresh for her support in data analysis, and express thanks to Sultan AlEnezi, Assistant Professor in faculty of Engineering, Kuwait University for his efforts in data collection. Finally, the authors express deepest gratitude to all Kuwait university students who participated in the study. 


\section{REFERENCES}

Abdel-Meguid, N., Zaki, M.S. and Hammad, S.A. (2000). Premarital genetic investigations: effect of genetic counselling. East Mediterr Health J, 6(4), pp. 652-660.

Al-Aama, J.Y., Nabulsi, K., Alyousef, M.A., Asiri, N.A. and Al-Blewi S.M. (2008). Knowledge regarding the national premarital screening program among university students in western Saudi Arabia. Saudi Med J, 29(11), pp. 1649-1653.

Al-Arrayed, S., Hafadh, N. and Al-Serafi, S. (1997). Premarital counseling: an experience from Bahrain. Eastern Mediterranean Health Journal, 3(3), pp. 415-419.

Al-Arrayed, S., Hafadh, N., Amin, S., Al-Mukhareq, H. and Sanad, H. (2003). Student screening for inherited blood disorders in Bahrain. East Mediterr Health J, 9(3), pp. 344-352.

Al-Arayyed, S, Hamza, A.A., Sultan, B., Shome, D.K. and Bapat, J.P. (2007). Neonatal screening for genetic blood diseases. Babrain Med Bull, 29, pp. 88-90.

Al-Awadi, S.A., Moussa, M.A., Naguib, K.K., Farag, T.I., Teebi, A.S., el-Khalifa, M. and el-Dossary, L. (1985). Consanguinity among the Kuwaiti population. Clin Genet., 27(5), pp. 483-486. https://doi.org/10.1111/j.13990004.1985.tb00236.x

Al-Farsi, O.A., Al-Farsi, Y.M., Gupta, I., Ouhtit, A., Al-Farsi, K.S. and Al-Aadawi, S. (2014). A study on knowledge, attitude, and practice towards premarital carrier screening among adults attending primary health care centers in a region in Oman. BMC Public Health, 14, 380. https://doi.org/10.1186/1471-2458-14-380

Alghamdi, A.M., Algadheb, A.F., Alzahrani, A.M., Aldhahri, A.S. and Alsharif, Z.M. (2016). Knowledge of premarital screening among male university students in Riyadh, Saudi Arabia. Int J Med Sci Public Health, 5(4). https://doi.org/10.5455/ijmsph.2016.21112015222

Al-Jasir, B., Little, J., Mandoura, N.A. and Al-Thani, M.H. (2009). Population health genomics in member countries of the Cooperation Council for the Arab States of the Gulf. Kuwait Med J, 41(3), pp. 187-204.

Al-Kandari, Y.Y. and Crews, D.E. (2011). The effect of consanguinity on congenital disabilities in the Kuwaiti population. J Biosoc Sci, 43(1), pp. 65-73. https://doi.org/10.1017/S0021932010000477

Alkhaldi, S.M., Khatatbeh, M.M., Berggren, V.E. and Taha, H.A. (2016). Knowledge and attitudes toward mandatory premarital screening among university students in North Jordan. Hemoglobin, 40(2), pp. 118-124. https:// doi.org/10.3109/03630269.2015.1135159

Al-Kindi, R., Al-Rujaibi, S. and Al-Kendi, M. (2012). Knowledge and attitude of university students towards premarital screening program. Oman Med J, 27(4), pp. 291-296. https://doi.org/10.5001/omj.2012.72

Bittles, A.H. (2001). Consanguinity and its relevance to clinical genetics. Clin Genet, 60(2), pp. 89-98. https://doi.org/10.1034/j.1399-0004.2001.600201.x

Ganczak, M. (2010). The impact of premarital HIV testing: A perspective from selected countries from the Arabian Peninsula. AIDS Care, 22(11), pp. 1428-1433. https://doi.org/10.1080/09540121003692615

Gharaibeh, A. and Mater, F.K. (2009). Young Syrian adults' knowledge, perceptions and attitudes to premarital testing. Int Nursing Review, 56(4), pp. 450-455. https://doi.org/10.1111/j.1466-7657.2009.00736.x

Keskin, A., Türk, T., Polat, A., Koyuncu, H. and Saracoglu, B. (2000). Premarital screening of beta-thalassemia trait in the province of Denizli, Turkey. Acta Haematologica, 104(1), pp. 31-33. https://doi.org/10.1159/000041066

McGeorge, C.R. and Carlson, T.S. (2006). Premarital Education: An Assessment of Program Efficacy. Contemporary Family Therapy, 28(1), pp. 165-190. https://doi.org/10.1007/s10591-006-9701-8

Memish, Z.A. and Saeedi, M.Y. (2011). Six-year outcome of the national premarital screening and genetic counseling program for sickle cell disease and beta-thalassemia in Saudi Arabia. Ann Saudi Med, 31(3), pp. 229235. https://doi.org/10.5144/0256-4947.2011.229

Ministry of Health, Kuwait. (2008). Kuwait premarital screening program: Healthy generation. Available at: https://www.yumpu.com/en/document/view/34011150/kuwait-premarital-screening-program [Accessed 28 Sep. 2017].

Old, J.M. (2009). Screening and genetic diagnosis of haemoglobinopathies. Scand J Clin Lab Invest, 67(1), pp. 71-86. https://doi.org/10.1080/00365510601046466

Olwi, D., Merdad, L. and Ramadan, E. (2016). Knowledge of genetics and attitudes toward genetic testing among college students in Saudi Arabia. Public Health Genomics, 19, pp. 260-268. https:/ / doi.org/10.1159/000446511

Saxena, A. and Phadke, S.R. (2002). Thalassaemia control by carrier screening: The Indian scenario. Curr Sci, 83(3), pp. 291-295.

Shah, N.M. (2010). Population of Kuwait structure and dynamics. Kuwait: Academic Publication Council - University of Kuwait.

Teebi, A.S. (1994). Autosomal recessive disorders among Arabs: an overview from Kuwait. J Med Genet, 31(3), pp. 224-233. https://doi.org/10.1136/jmg.31.3.224 
van El, C.G. and Cornel, M.C. (2011). Genetic testing and common disorders in a public health framework. Eur J Hum Genetics, 19, pp. 377-381. https://doi.org/10.1038/ejhg.2010.176

Wang, P., Wang, X., Fang, M. and Vander Weele T.J. (2013). Factors influencing the decision to participate in medical premarital examinations in Hubei Province, Mid-China. BMC Public Health, 13, pp. 217. https://doi.org/10.1186/1471-2458-13-217 